\title{
From the sacred to the profane: connections between Christian theology and administration
}

\author{
Aline Van Neutgem ${ }^{1}$ \\ Eloise Helena livramento Dellagnelo ${ }^{2}$

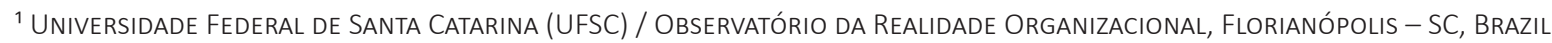

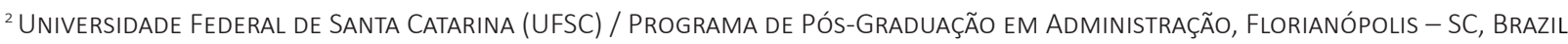

\begin{abstract}
This theoretical essay aimed to make connections between Christian theology and administration. Starting from the ideas of Agamben (2008), attempts were made to establish relations between aspects of Christian theology and its trinitarian order with the characteristics of bureaucratic and flexible organizations. The intention was to unveil the sacredness and deity in these organizations, despite the idea of secularization and rationality, in the Weberian sense related to them. From these relationships and the observation of a new kind of sacralization in these organizations, which maintains the divine ideology and makes economic power, money, technique, and formal logic sacred over everything else, this essay advocates for the desecration of the Sacred. It is understood that this can take place through reflections about inoperosity and its relationship with politics and aesthetics, which refer to a new possibility of using the ideas of pleasure, desire, and body.
\end{abstract}

Keywords: Christian Theology. Bureaucracy. Flexible organizations. Power. Aesthetics.

\section{Do sagrado ao profano: aproximações entre a teologia cristã e a administração}

\section{Resumo}

Este ensaio teórico procurou realizar uma aproximação entre a administração e a teologia cristã. Para tanto, a partir, principalmente, das ideias de Agamben (2008), procurou-se estabelecer relações entre aspectos relativos à teologia cristã e sua ordem trinitária com as características de organizações burocráticas e flexíveis, no intuito de desvelar a sacralidade e a deidade presente nessas organizações, a despeito da ideia de secularização e racionalidade, no sentido weberiano, impetrada às mesmas. A partir dessas relações e da observação de um novo tipo de sacralização nessas organizações que, sem romper com o ideário divino, tornam sagrado o poder econômico, o dinheiro, a técnica e a lógica formal sobre tudo o mais, advoga-se pela profanação do sagrado. Entende-se que essa saída pode se dar por meio das reflexões acerca da inoperosidade e sua relação com a política e a estética, que remetem a uma nova possibilidade de uso do prazer, do desejo e do corpo.

Palavras-chave: Teologia cristã. Burocracia. Organizações flexíveis. Poder. Estética.

\section{De lo sagrado a lo profano: aproximaciones entre la teología cristiana y la administración}

\section{Resumen}

Este ensayo teórico buscó realizar una aproximación entre la teología cristiana y la administración. Para ello, a partir, principalmente, de las ideas de Agamben (2008), se buscó establecer relaciones entre aspectos relativos a la teología cristiana y su orden trinitaria con las características de organizaciones burocráticas y flexibles, con el fin de desvelar la sacralidad y la deidad presente en estas organizaciones, a pesar de la idea de secularización y racionalidad, en el sentido weberiano, atribuida a las mismas. A partir de esas relaciones y de la observación de un nuevo tipo de sacralización en estas organizaciones que, sin romper con el ideario divino, hacen sagrado el poder económico, el dinero, la técnica y la lógica formal sobre todo lo demás, se aboga por la profanación de lo sagrado. Se entiende que esa salida puede darse por medio de reflexiones sobre la inoperosidad y su relación con la política y la estética, que remiten a una nueva posibilidad de uso del placer, del deseo y del cuerpo.

Palabras clave: Teología cristiana. Burocracia. Organizaciones flexibles. Poder. Estética. 


\section{INTRODUCTION}

Based on Agamben's (2008) investigations, for which the secularization of sacred issues in modernity takes place as a signature, constituting a reference of modern and rationalized concepts to a theological origin, this theoretical essay sought to bring together Christian theology and the administration. Thus, we sought to establish relationships between aspects related to Christian theology and its Trinitarian order with the characteristics of bureaucratic and flexible organizations, in order to reveal the sacredness and deity present in these organizations, whether through formal aspects or glorious aspects, always covered by a layer of rationality and logicity.

This discussion is part of the research that articulates the religious issue with organizational studies, a theme that, according to Tracey (2012), still needs further investigation. Among the research already carried out, some general approaches can be highlighted, based on Tracey (2012) and authors who worked on these subjects. In this sense, there are discussions about the relationship between religious organizations and the context in which they are inserted, reflecting on the effects of religious beliefs and values in the cultural and institutional environment or on the adaptation of religious organizations to a market situation, using contributions such as Field theory, Theory of economic development, Theory of Stakeholders, Theory of social capital and Theory of rational choice, among others (COSGEL and MINKLER, 2004; MARTES and RODRIGUEZ, 2004; PARKER and BAKER, 2007; SERAFIM and ANDION, 2010; OLIVEIRA, CORTES and BALBINOTTO, 2011; SERAFIM, MARTES, and RODRIGUEZ, 2012; SERAFIM and FEUERSCHÜTTE, 2015; ENOQUE, BORGES and BORGES, 2015; CUNHA, SOUZA, MACAU, et al., 2016; BAZANINI and GIGLLIN, 2017; CORRÊA, VALE e CRUZ, 2017; BERNARDELLI and MICHELLON, 2018; PAIVA, SOUSA, LIMA, et al., 2020; SOUSA, PAIVA, SANTOS et al., 2020).

Some studies focus on the relationship between religion and individual behavior in organizations, covering ethical behavior, values, and attitudes. They use varied references, among them Institutional Theory and Positive Psychology (NELSON, 1993; ASHMOS and DUCHON, 2000; DUCHON and PLOWMAN, 2005; NASCIMENTO, 2005; STEINGARD, 2005; ALBAUM and PETERSON, 2006; KELLER, SMITH and SMITH, 2007; WALKER, SMITHER and DEBODE, 2012; VASCONCELOS, 2015; MARTINEZ and COELHO, 2019). Finally, the discussion on religious ideas in secular contexts also stands out, incorporating studies investigating the penetration of religious ideas and practices in other types of organizations. Regarding forms of investigation, some of these researches mobilize theoretical matrices such as Psychoanalytical Analysis and Critical Discourse Analysis, while others dialogue with Weber and discussions typical of classical organizational theory (PAGÈS, BONETTI, GAULEJAC et al., 1993; PRESTES MOTTA, 2001; ASHFORTH and VAIDYANATH, 2002; FINCH-LEES, MABEY and LIEFOOGHE, 2005; HARRISON, ASHFORTH and CORLEY, 2009).

This article is part of the studies that Tracey (2012, p. 124) understands as "religious ideas in secular contexts", which the author says are essential because "they call into question the neat distinction between religious and secular organizational forms 'and because' we still have a relatively rudimentary understanding of the role of the sacred and the dynamics of sacralization in secular organizational forms". Discussions in this direction generally encompass the sociology of religion using different perspectives and authors on their approach to the organizational theory, from classics like Durkheim, Weber, and Marx, to contemporary thinkers like Peter Berger, for example, whose ideas seem to have particular adherence within organizational studies.

Berger's reading maintains that there was no secularization as a break with religion, but that there is a coexistence - with contamination and bargains - between secular discourse and religious discourses, in the manner of pluralism, in which such discourses are presented to individuals as options to be chosen. In this view, there are institutional spheres that operate independently of religious values, such as trade and bureaucratic apparatus (BERGER, 2017). Other readings, such as radical Orthodoxy or, in the field of administration, the organization based on spirituality, also criticize the thesis of secularization but point to spirituality as a response to secular nihilist theories represented by a material paradigm (MILBANK, 1995; VASCONCELOS, 2015).

In organizational studies, it is also worth highlighting the critical analyzes of this idea of secularization undertaken by Pagès, Bonetti, Gaulejac et al. (1993, p. 76), who affirm that "we are facing a religious system, and this is not a simple metaphor" and add that "the essential values of the humanist Christian ideology (...) are alleged to mask real conditions exploration". For the authors, "this discourse is closed, it is impossible to escape it" (PAGÈS, BONETTI, GAULEJAC et al., 1993, p. 85). Our article shares this diagnosis, but it is more suited to the studies by Finch-Lees, Mabey, and Liefooghe (2005), 
which, based on a discursive investigation of the theme, present the possibilities of resistance in this paradigm. Thus, the ideas of the Italian philosopher Giorgio Agamben is proposed as a contribution to this discussion; still little worked in administration and whose investigations in the field of theology, politics, and power can be useful not only for problematizing aspects of bureaucratic and flexible organizations but also to imagine other possibilities of organizing. According to Phelps (2012, p. 1), "Agamben's reading of the theological tradition represents a concerted effort to profane that tradition, to render it inoperative for a new use".

However, it is essential to note that the present proposal was not intended to end a reference by these organizations to their divine originality or to a specific theological model. We are not unaware that some other relationships and origins may influence their ways of organizing and the relations of power and domination that permeate them, already pointed out by works that discuss the transition from the bureaucratic to the flexible form much more as an adaptation than as a rupture (PAES DE PAULA, 2002; SILVA, 2003; BÖHM, 2005; PALMER, BENVENISTE and DUNFORD, 2007). In this way, the objective was undoubtedly to shed light on the possible relations and references between the divine oikonomia organization and the bureaucratic and flexible organizations, seeking to understand the implications of this origin in crystallization of practices of subjection and subjectification within these organizations.

In the sections that follow, we tried to problematize the notion of Weberian secularization, which is often worked on in the scope of organizational studies, and recover aspects related to bureaucracy and flexible organizations, seeking to signal its identification with sacred elements. In the end, based on the analysis carried out, some reflections and notes are made about the possibility of interrupting this new tabernacle, which is the empire of economic power, technique, and reason over all forms of organizing society and human life, by articulating the idea of inoperativity and its relationship with politics and aesthetics, which refer to a new possibility of using pleasure, desire, and the body.

\section{SECULARIZATION AS A SIGNATURE}

Max Weber, an influential theorist of sociology and a significant influencer of administrative thought, dedicated himself to studying the "process of rationalization in the sphere of religion, morals, law, art, economics, politics, etc.", trying to demonstrate that there was, in the modern age, a rupture with traditionalism and with the "social organization founded on the sanctity of tradition" (RAMOS, 2006, p. 271-272). According to Ramos (2006), for Weber, the ratio is par excellence, the instrument of secularization, making it possible to eradicate the sacred's fear. In the Weberian sense, secularization would increase the disenchantment and detheologization of the modern world.

To achieve the approximations between Christian theology and administration, which is intended in this theoretical essay, it is necessary to clarify secularization engenders meaning and implications. According to Agamben (2008), the concept of secularization played a strategic role in modern culture, both in its strictly legal sense and in its metaphorical use in the history of ideas. For Agamben (2008, p. 17), "when Max Weber formulates his famous thesis about the secularization of Puritan asceticism in the capitalist ethic of work, the apparent neutrality of his diagnosis cannot hide its function in the battle he was fighting for the disenchantment of the world" that Weber opposes to fanatics and false prophets.

Later, another German intellectual, Carl Schmitt, proposes a debate about secularization from Weber's different terms. According to Agamben (2008, p. 19-20), at the center of this debate was the thesis that "both German idealism's philosophy of history and the Enlightenment's idea of progress are nothing but the secularization of the theology of history and Christian eschatology" which is in line with Hegel's theories, who "was perfectly aware of this when he stated the equivalence of his thesis on the rational government of the world with the theological doctrine of the providential plan of God, and presented his philosophy of history as a theodicy". In this sense, it is possible to observe that Schmitt's conception is opposite to that of Weber. For Schmitt, secularization strategy attests that theology is still present and acts imminently in the modern world, and there has not been a rupture with the tradition of holiness. It is necessary to assert, however, that this does not imply "a perfect identity of meaning between theological concepts" and modern ones; "it concerns a particular strategic relationship," which marks such concepts "refers them back to their theological origin" (AGAMBEN, 2008, p. 17-18). 
Understood in this way, as a strategic relationship that refers to the theological origin of political concepts in the modern period, secularization does not represent a concept, but rather a signature, in a sense found in Foucault and Melandri. The signatures have a genuine historical character since they constitute a network of references and time quotes that do not cease. Thus, they represent the other in the same one, the old that becomes new within each statement, in a (re) organization and (re) articulation of discourses, without thereby constituting a new meaning or concept (FOUCAULT, 1996). In other words, signatures move concepts from one sphere to another without thereby redefining them semantically. Therefore, secularization acts in the modern conceptual system as a signature that makes temporal reference to theology, denoting in modernity a belonging to divine oikonomia (AGAMBEN, 2008). This theoretical essay aims to bring together Christian theology and administration, seeking to demonstrate that Christian religious dynamics have a close relationship with economic and administrative dynamics, which is in line with this understanding of secularization.

Along the same lines, Adorno and Horkheimer $(1985$, p. 6) state that the program of enlightenment, that is, of secularization, which consisted of disenchanting the world and overcoming metaphysical explanations based on gods, inculcated a new metaphysics, based on a formal and ordering logic. According to the authors, technical reason becomes the essence of modern knowledge, "which does not aim at concepts and images, nor the pleasure of discernment, but the method, the use of the work of others, the capital". In this way, Adorno and Horkheimer $(1985$, p. 6) inform that "as sovereigns of nature, the Creator God and the ordering spirit are equal" because "the myths that fall victims of enlightenment were already the product of enlightenment". In this sense, instead of a God's sacralization, a new sacralization occurs: economic power, money, technical reason, and formal logic. If this is true, all the decisive concepts of modern science are secularized theological concepts, that is, clothed with modern reason but originating in theology. According to Agamben (2008, p. 16), "this [previous] statement should be supplemented in a way that would extend its validity well beyond the boundaries of public law, extending up to the fundamental concepts of the economy" and life in society. For the Italian philosopher, the oikonomia of the moderns, assuming a sovereignty separated from its divine origin, maintains, in reality, the theological model of government of the world.

In this sense, when observing bureaucracy as an organizational expression of a type of rationalized thought and society, one cannot ignore the deity still present in modern society's organization forms. As will be discussed below, the bureaucracy itself and, later, the so-called flexible organizations mostly take over or preserve elements of Christian theology and aspects of its divine administration. For Agamben (2008, p. 497), there is identification in the image of the world with and without God: "contingency and necessity, freedom and slavery all merge into one another". In this kind of categorical ambivalence, "modernity, removing God from the world, has not only failed to leave theology behind, but in some ways has done nothing other than to lead the project of the providential oikonomia to completion". In other words, in modernity, reason fulfills the function of keeping a particular order of the world unscathed, but now under the aegis of formal logic and modern economics.

Thus, according to Nietzsche (2001), even after the death of God, their shadows still fall on men. For the philosopher, modern science pretends to abolish God. However, it reinstates its shadows - the belief in a rational world, the pure laws of logic, the cosmos governed by logos, etc. - through philosophical rationalism and belief in science, variations of the old religious and moral order. New ideas now inhabit the sphere of the sacred, constituting other axioms, universal and untouchable statements. According to Souto $(2011$, p. 134), for Nietzsche, "Christianity would have extended the Platonic doctrine of both worlds to the people, converting their philosophical values into moral values (...). Therefore, with Christianity, a moral arose from the denial of strong values and degeneration of life". This degeneration of life is carried to its ultimate consequences in a capitalist society, in which the being is shaped by manipulation and administration. Based on these theorizations, we seek to achieve some approximations between Christian theology and administration, demonstrating secularization as a signature of sacred aspects in practices and administrative thinking concerning bureaucratic organizations and, later, in a more sophisticated way, on flexible organizations, since the latter do not break with the foundational aspects of the former (PAES DE PAULA, 2002; SILVA, 2003; BÖHM, 2005). 


\section{APPROACHES BETWEEN ADMINISTRATION AND THE SACRED}

According to Bédard (2004), the sacred is historical and contextual and designates what man considers as positive and negative powers in a given sphere, or what is worthy of respect. Thus, investigating the approximations between the administration and the sacred becomes crucial to understand better the practices and administrative thinking and the power, domination, submission, and governance (or pastoral) relationships. For Agamben (2008, p. 91), Christian theology has a strong influence on the thought and on the social organization of the West and, far from being just a "story about the gods", it is "immediately economy and providence, that is, an activity of self-revelation, government, and care of the world". The Christian divinity is articulated through a Trinity ${ }^{1}$ (father, son, and holy spirit), which is not a theogony or mythology, but an oikonomia, that is, an articulation and an administration of the divine life and government of the creatures. Bédard (2004, p. 101) explores the sacred side of administration - or the administrative side of the sacred - in arguing that

Both official and exclusive representative of the sacred and values, the leader, whatever his hierarchical level, is a "grand priest" who presides over all kinds of rites: official representations and ceremonies, sanctions and promulgation of their official texts, reception of outstanding visitors and a whole series of emblematic and protocolary activities.

In Agamben's (2008) work, there is also evidence of the relationship between administration and the sacred through a divine oikonomia. According to the author, the gospel of Paul not only refers to an oikonomia of God but also refers to himself and the members of the messianic community with terms that belong exclusively to the vocabulary of domestic administration: doûlos ("slave"), hyperétes, diakonos ("created"), oikonómos ("administrator"). Therefore, there has been a long-standing close relationship between the administration and Christian theology, as the term's very origin is intertwined with religion. For the author, one can speak of a theological paradigm of administration, which finds its perfect example in the angelic hierarchies, which will be explored below.

When dealing with the restitution of oikonomia as a government of men, which involves the administration of a complex social organism, permeated by several relationships, Agamben (2008, p. 81-82), recovers the origins of the term administration. According to the author, "the definition of the juridical-political concept of 'administration' has always been problematic for historians of law and politics", who found the origin of the term in the canon law of the 12th and 14th centuries, "when the term administratio begins to appear together with jurisdictio in the terminology of canonists".

The notion of oikonomia is essential here because in instituting a Trinitarian, a hierarchical oikonomia, Christian theology distributed power in a certain way but without dividing the central unit. The Trinitarian hierarchy members invested with fractions of divine power to carry out their tasks, glorify and reinforce, in a way, the original figure of power. Another critical issue is that the notion of oikonomia is precious and is in line with the theological objective because it promotes the politician's concealment. These two central issues - the apparent distribution of power and political concealment - are also fundamental, as will be discussed below, in understanding the organizational dynamics of bureaucracy and flexible organizations.

\footnotetext{
${ }^{1}$ The question of the Trinity in Christian theology remains controversial, being discussed by theorists like Carl Schmitt, who bring transcendence to immanence and vice versa, or like Erik Peterson. He suggests the definitive separation between immanence and transcendence. Agamben starts from Carl Schmitt and understands that "the fracture originally exposed between transcendence and immanence, arising from Aristotelianism, is resignified by Christian theology, so that the Christian God is the one in which transcendent order and immanent order are mutually related, passing from one to the other" (PFISTER, 2019, p. 53). Agamben (2008, p. 102) puts the question in the following terms: "if we take the paradigm of the separated substance to the extreme, we have gnosis, with its God foreign to the world and creation; if we follow the immanence paradigm to the last consequences, we have pantheism. Between these two extremes, the idea of order seeks to think of a difficult balance, from which Christian theology is always falling and which it must reconquer each time". Gregório de Nissa, a Cappadocian theologian, is the one who tries to stop the split of the being of God and his praxis, signaling that "God would be one in substance and triune in his economy, without any rupture in communion" and, even if different in number, it would not be divided as to the substance (PFISTER, 2019, p. 42). This duality is between immanent and economic Trinity- marked by a series of complementary divisions, in the center of which is Glory, which, for Agamben (2008), allows the divine governmental machine over men in the world to function.
} 
Still, regarding oikonomia or divine administration, Agamben (2008, p. 41-42) clarifies that the notion rescues Aristotelian thought and warns that

Oikonomia means "administration of the house". In the Aristotelian treaty (the pseudo-Aristotelian) on economics, one can see that the téchne oikonomiké is distinguished from politics, as the house (oikia) is distinguished from the city (polis). [...] It is necessary not to forget, however, that not only is the modern single-family house simply the extended family, but it also is not a complete organism in which heterogeneous relationships intertwine, which Aristotle (Pol., 1253b 1-10) distinguishes in three groups: master-slaves "despotic" relationships [...], priest-sons "paternal" relationships, husband-wife "marital" relationships. What unites these "economic" relationships [...] is a paradigm that we could define "of management" [...]: it is not only concerned with the need and use of objects, but above all with their orderly arrangement.

The orderly arrangement, which conforms to a kind of harmony that hides issues of conflict, struggle, and tension present in these heterogeneous relationships, is also an essential element for the maintenance of oikonomia and management, insofar as only the shift from political to economic rationality would be able to protect the divine organization against the danger of internal stasis (AGAMBEN, 2008).

As can be seen, oikonomia is characterized here as a functional organization, as a management activity that exercises a government of men and is not bound by rules other than the orderly functioning of the "house" or the organization in question. It is this management paradigm, in the words of Agamben (2008, p. 43-44), that "defines the semantic sphere of the term oikonomia (...) and determines its gradual analogical extension outside its original limits".

Suppose, according to Agamben (2008), it is a sacred order that influences the constitution of society's organization under a management paradigm, on that case, one can now think that management itself, with outlines of technical rationality and formal logic, becomes sacred in our time. The naturalization of management based on formal rationality as the only correct and possible way of managing organizations certainly reinforces social conventions that support asymmetric power forms. In this project, which some authors call managerialism, the exact positioning of an idea of modern organization and its related organizational theories goes a long way towards stimulating techniques that perpetuate the ideas of the modern organization (TRAGTENBERG, 2005; PAES DE PAULA, 2002; PARKER, 2002; BÖHM, 2005; IBARRA-COLADO, 2006; FARIA and MENEGHETTI, 2011; SPICER, ALVESSON and KARREMAN, 2009, 2016). This idea - which we argue to be substantially theological - of a natural order of things and subjects, of their positions and their destiny in the world, contributes to perpetuating injustices and to maintaining a political uprooting of the subjects concerning their social context.

\section{BUREAUCRATIC ORGANIZATIONS AND ANGELOLOGY}

Intending to shed light on the connection between administration and Christian theology, this essay approaches bureaucratic and flexible organizations with divine administration characteristics. This section presents this relationship involving bureaucratic organizations, which inherit many theological aspects, bringing this discussion closer to organizational theory literature.

As Böhm (2005, p. 4) argues, "our seeing [of the world] is based on the way the world is emplaced as the particular organizational regime of modern technics". According to the author, this organizational regime is related to modernity and capitalism. Things start to be placed in a defined and safe place, containing notions constructed as a neutral and correct form of what they intend to mean. Thus, in modern times, an organization's notion is constructed and positioned as a bureaucratic organization related to the administration and maintenance of a technically ordered world and characterized by clear divisions of work and by rational bodies that can be ordered and measured.

According to Prestes Motta (1991), the term "bureaucracy" has been used in several ways: to designate a rational and efficient administration - or the opposite, a government of employees or even the organization itself. According to the author, bureaucracy is all that, since it is power, control, and alienation. According to Faria and Meneghetti (2011), power is expressed in the bureaucracy through the relations of domination existing in this type of organization, capable of 
perpetuating social positions and forms of political and economic domination based on a rational/legal logic. As a control, the bureaucracy manages to establish domain relationships through objective means or through the intersubjective domain (in which there is an essential ideological factor), using various devices ${ }^{2}$ such as technology, codes, procedures, and the imaginary itself. Finally, like alienation, the bureaucracy acts in such a way as to make individuals to internalize the bureaucratic way of thinking, feeling, acting. As it is explained by Faria and Meneghetti $(2011$, p. 434), "the ideological inculcation, submission, standard behaviors and disciplining are not just due to the objective way in which bureaucracy is established in the organization".

These three determinant aspects of bureaucracy - power, control, and alienation - permeate Weber's ideal bureaucratic type elements. In elements such as formalism, impersonality, and hierarchy, it is possible to observe the underlying power, control, and alienation (PAES DE PAULA, 2002). For us, these characteristics are advantageous to carry out the exercise of reflecting on the possible references of theological aspects in bureaucracies, which succeed in a rationalized, divided, and disqualified work platform (TRAGTENBERG, 2005; FARIA and MENEGHETTI, 2011). Bureaucracy, a modern organization that is forged in the process of clarification, breaking with the sacred, with the deity, with scholastic philosophy and all metaphysical explanations, constitutes, we argue, a signature that brings us back to theology. Based on formalism and hierarchy, its structure resembles Christian angelology ${ }^{3}$, in which the sensitive issues of power, control, and alienation are preserved, as we try to reflect below.

Modern bureaucracy works in specific ways, characterized, for example, by being

under the regulation of fixed and official jurisdiction areas, ordered by laws and administrative rules. It establishes relations of authority, bounded by rules relating to the means of coercion and consensus. A hierarchical relationship is established, defining posts and levels of authorities and a system of command and subordination with the management of activities and tasks delegated by the authority. In this context, management is formalized through documents, which end up regulating people's conduct and activities (FARIA and MENEGHETTI, 2011, p. 427, emphasis added).

This ordering formalized by rules that regulate the conduct and activities of individuals, as well as the hierarchical relationship that is established by defining levels of authority and the dynamics of the command system, refers to the organization of divine administration in Christian theology, which has the same functional structure expressed in an economic Trinitarian order. With a vertical hierarchy well delimited by various administrative functions and different guiding devices of divine and earthly life, like the commandments and gospels, divine oikonomia manages individuals who are heterogeneously related in oikós.

To illustrate the economic aspect of the administration mobilized in the Christian Trinitarian order, Agamben (2008, p. 83) "mobilizes angelology as a theological paradigm of the administration, thus instituting, with a quasi-kafkian move, a correspondence between angels and officers" in a way to organize and distribute - or not - power. This parallelism between the angelic hierarchy and the bureaucratic hierarchy can be illustrated by the image of Jacob's ladder, found in the book Genesis of the Old Testament and portrayed by the painter and poet William Blake in 1805:

The angelic operations can be reduced to two: the contemplative operation and the administrative [...] And it is through these two that the angelic spirits and their operations are distinguished. The contemplative consists in an ascent to the highest things, the administrative in the descent to human ones. The two encounter one another on the ladder on which the angels climb and descend... (AGAMBEN, 2008, p. 261).

In the previous passage, it is possible to observe that, in the angelic hierarchies, there is a separation between angels that perform contemplative operations, related to the interpretation of the divine mystery, and angels that perform ministerial, administrative operations, related to manual tasks. This separation remains a signature in bureaucratic organizations

\footnotetext{
${ }^{2}$ The devices, which are all things that "can somehow capture, guide, determine, intercept, model, control and ensure the gestures, behaviors, opinions, and discourses of living beings", contribute to perpetuate and naturalize the behavior of individuals according to hegemonic precepts (AGAMBEN, 2009, p. 40-41). According to Agamben, not only the institutions (schools, asylums, churches, factories, etc.), whose connection with power is in a certain evident sense, but also the pen, writing, literature, technology, etc., have, somehow, the ability to shape human behavior. Thus, the organizational model proper to this modern oikonomia, the bureaucracy, operates a process of training individuals' souls.

${ }^{3} \mathrm{~A}$ branch of theology that studies angels regarding their nature and their functions.
} 
because, as Faria and Meneghetti (2011) and Prestes Motta (1991) state, there is a Taylorist separation between intellectual and manual work in the bureaucracy. It is interesting to note that Taylor himself comes from a rigorous and puritan family, which is reflected in his scientific, emotionally inert, and highly formal management.

Agamben (2008) adds to these hierarchical separations by stating that all angels can see the divine essence. However, only those of a higher degree can understand the divine secrets and mysteries, and these are the angels who transmit the secrets as a revelation - to the lower angels. This aspect corroborates Weber's description that the bureaucracy, through its hierarchy, "potentiates secrets, knowledge, and intentions", tending towards "an organized structure of small secret sessions, insofar as it hides knowledge and actions" (FARIA and MENEGHETTI, 2011, p. 427).

It should be noted that this hierarchical principle proper to angelic functions is elevated to universal law, also implying civil hierarchies, as can be seen in the social sphere and in the bureaucracy in which there is a clear division of functions and positions held. The division of labor, argues Tragtenberg (1974), has broad cultural, ideological, and political implications because it removes worker's understanding of the whole process, fragmenting their consciousness. The author adds that it is the bureaucratic structure that guarantees obedience to orders and consolidates these separations between types of work and types of workers, since "people are alienated in roles, and these are alienated in the bureaucratic system" (TRAGTENBERG, 1974, p. 196). In this sense, the centrality of hierarchy and order is verified in this parallel between divine and bureaucratic administration and, thus, angels and bureaucrats tend to be confused, as in a Kafkinian universe:

not only the heavenly messengers are arranged according to offices and ministries; Earthly functionaries also acquire angelic faces and, like angels, become capable of purifying, illuminating, and perfecting. [...] In any case, what is decisive is that long before the terminology of administration and the civil government began to be elaborated and established, it was already firmly established in the field of angelology. As we have seen, the concept of hierarchy and those of ministry and mission find a first and articulated systematization of angelic activities (AGAMBEN, 2008, p. 276-277).

In this way, through laws, norms, commandments, and codes, with a documentary and, in a sense, legal function, that divine ordination according to an angelic hierarchy remains, which denotes an evident connection with aspects of modern bureaucracy. This formalism in the Christian theological sphere takes the form of "consecration". According to Ludueña Romandini (2011, p. 104-105, free translation), through a sacrament - which is valid as a law - the entrance into the sacred world is consecrated: "the entrance to the Christian Church itself is through a sacramental act in the inclusion - by baptism of a new member". Here, an analogy can be made with the process of entering an individual into a bureaucratic organization: employing a contract, which enshrines the individual as a member of that organization, a rite of education and discipline of his body, his wills and actions begins.

Besides, the individual will then go through a series of socialization processes to adapt his personality to the bureaucratic personality. According to Prestes Motta (1978, p. 71), "these individuals are expected to be loyal, to behave rationally according to technical and professional criteria, and to deference to the authority of senior managers", which "presupposes a process of accommodation by which certain values are inculcated in individuals, thus occurring an intra-organizational socialization process". For Ludueña Romandini (2011, p. 106, free translation), in Christian theology, "the consecrated subject transmutes his own ontological substance" from his entry into the celestial hierarchy, and "this sacramental character alienates the subject from any intimate bond with the earthly world that, however, must inhabit, as a foreigner, throughout his life".

So it is also with the socialized subject within the bureaucracy, who, through alienating training, becomes no more than an occupant of the office. Through education (in theology with sermons, cults, catechesis, and bureaucracy through individual and collective training and guidance), the personality shaped in the subjects advocates obedience, resistance to frustration, the ability to postpone rewards and permanent desire of accomplishment, essential characteristics for the maintenance of the domination and the asymmetry of power present in the hierarchies, whether celestial or bureaucratic (PRESTES MOTTA, 1981).

According to Faria and Meneghetti (2011, p. 427), these socialization processes are also critical because they transform work into a profession, making it impersonal and favor regular activities that everyone can learn. Because of this impersonality, 
"an employee's position is enjoyed and estimated in a specific social context, always compared to other employees and concerning the social structure". As an attribute of bureaucracy, impersonality refers to the impersonal exercise of power already present in Christian sacramental theology during the Middle Ages. Ludueña Romandini explains (2011, p. 108):

As the medieval treatises on the sacraments already pointed out, even if the official is devoid of faith, his action will be valid as long as he performs the formal external act. Therefore, whether a minister hates the Church or is indifferent to himself (as in the example of Max Weber), bureaucratic action is completely effective since its strength comes from spiritual power (or, in its secularized version of the law) that institutes the official as such and not of the ethical world or its internal jurisdiction.

Finally, social control develops in the bureaucratic organization as an instrument for maintaining order and apparent social harmony, obtained through political concealment and the neutralization of conflict (PAES DE PAULA, 2002; BÖHM, 2005). Control is an instrument of power and domination and designates senior officials evaluation and judgment against lower officials based on domestic law. This is also true in theology, where confession fulfills the investigation's role, on the part of the superior official (such as the priest, for example) of the activities, the wills, and individual's actions in hierarchically inferior functions. Likewise, this information is confronted with scripture and the sacred command, resulting in punishments or rewards (not necessarily material). Once again, there is a reference of bureaucracy to theology as a secularized theological concept or practice in the sense of its signature.

\section{FLEXIBLE ORGANIZATIONS, GLORY AND THE PASTORATE}

"God irresistibly governs everything, but sweetly and without violence, so that man believes he is following his will while executing God's."

(Gottfried Wilhelm Leibniz).

According to Clegg (1998), it is mainly from the 1980s that different forms of organization and questioning of the bureaucratic model begin to emerge as the most efficient way of organizing work - these are called postmodern organizations. Some authors, however, disagree that these organizations are essentially different from bureaucratic ones, like Thompson (1993), for example. According to the author, it is necessary to consider that elements emphasized as typical of an organization's bureaucratic model - the calculation of consequences, the search for predictability, etc. - do not appear to have been abandoned. This conclusion is echoed in the work of Paes de Paula (2002, p. 137-138), in which the author affirms that the reduction of bureaucracy is a fallacy and that, in fact, "it is an ideological operation, which hides new relationships of power and domination".

Postmodern or flexible organizations "represent an adaptation of theories and practices to flexible capitalism" (PAES DE PAULA, 2002, p. 136) and are characterized by: emphasizing more frequent and faster decision-making; abolition of rigid controls; flexible working hours and ways of working; the continuous acquisition of information; empowerment; the more targeted distribution of information; the most charismatic leadership and the best management of organizational learning (HUBER and GLICK, 1995; GRAY and GARSTEN, 2001). Thus, in this new type of organization, centralization, vertical hierarchy, authority based on rules, discipline, and division of labor, distinctive aspects of bureaucracies give rise to decentralization, connection by information technology, facilitating leadership and cooperation-based work. Paes de Paula (2002, p. 138-139) explains that "bureaucracy reinvented hierarchy and sophisticated control mechanisms, making its attempts to harmonize tensions between capital and labor even more disguised, reducing the possibilities of human emancipation in the sphere organizations".

Silva (2003) asserts that postmodern organizations, which disguise offering more autonomy to their members than in bureaucratic models, have the potential to promote even more insidious control, like an iron fist in a kid's glove. Pagès, Bonetti, Gaulejac et al. (1993) have already signaled flexible organization's ideological dominance, identifying them with religious system's fundamental mechanisms. In this sense, not only is there no split with the bureaucratic model, but there is also a reference of theological aspects. However, in postmodern organizations, the connection with the sacred refers 
less to structure and more to symbolic and Glory ${ }^{4}$ aspects. As in the Christian Trinity, in which God presents himself as one in substance and triune in his economy, without any rupture of communion occurring, on flexible organizations, it is also possible to identify that empowerment, or the apparent distribution of authority, far from signifying the dissolution of central power, it reinforces and legitimizes power asymmetries: the economy glorifies the being, and the being glorifies the economy (SILVA, 2003; AGAMBEN, 2008; PFISTER, 2019).

Thus, there is always a single or divine figure that directs doing, even if implicitly, even in an environment where the formal hierarchy dissolves. This "one", this subjective figure of power, softens conflicts and harmonizes the whole. The group itself, which in flexible organizations apparently overlaps with a single leadership figure, legitimizes power owners, which has not been distributed. According to Agamben (2008, p. 77), divine oikonomia is also constituted as an "harmonious economy [oikonomia symphonías]", which, despite its group of members that perform different functions and have fractions of power, "results in a single God".

The apparent absence of the control figure does not imply that, on flexible organizations, there is no surveillance and command, which start to occur in a more sophisticated way (SILVA, 2003). According to Tragtenberg (2005, p. 26-28), even in business structures "stripped of rigid formalism, the subordinate maintains an ambivalent reverential fear before his superiors, fear is based on aggressiveness and seduction, excluding effective neutrality". For the author, control takes place in these organizations more symbolically and subjectively, as trained executives seek to intervene on the human and social level through a "moralizing literature with colloquia and seminars that show how executives are concerned with creating a semi-missionary role in the organization". In this sense, "modern inquisitors", in Tragtenberg's words, are convinced that their message carries a truth, more or less as the unique and divine truth, the object of Christian missionaries.

Still, according to Tragtenberg (2005, p. 31), the organization that seeks to spread participationism as a way of replacing rigid hierarchies maintains the principle of authority unscathed since, inspired by priests and psychiatrists, it discovers that the technique of non-directivity is much more effective in human control than interrogations and other systematic and coercive measures. In this sense, the domestication of the individual by the company occurs. The latter appears as "the new tabernacle, provides the security, support, and advice of the old churches, except that the new cleric is the administrator".

Our own conceptions of authority reproduce a logic based on social representations, generally unconscious. Starting from the ideas of Tragtenberg (2005) and Agamben (2008), one can problematize the figure of the "born" boss or the "born" salesperson, for example, in which certain people would have a specific superior vocation or would be predestined to command or obey, even in a relationship of apparent horizontality, in which some individuals "naturally" stand out in a certain sense. However, this natural ordering of individuals, divided into masters and servants, is not natural but expresses a divine ordering of the world according to mysterious criteria such as vocation and predestination.

With the horizontalization of the structure in flexible organizations, the physical figure of power leaves the scene, generating a kind of "empty throne". Moltmann (2000, p. 170) clarifies that in the divine post-judgment when all oikonomia activity ceases, that is, "when everything is 'in God' and 'God is all in all' (...) that will remain is the eternal hymn of praise from the one and triune God in his Glory". For Agamben (2008), however, God's inoperativity ${ }^{5}$ does not mean that the divine administration disappears from the world in its relationship with men's government. The author argues:

An idle God is an impotent God who has abdicated any government in the world (...) To avoid the total disappearance of all powers, they [theologians] separate him from his exercise and claim that power does not disappear but ceases to be exercised, thus assuming the immobile and resplendent form of Glory (in Greek, doxa) (AGAMBEN, 2007, p. 41).

Agamben (2008, p. 265) points out that "in the iconography of power (...) this central emptiness of Gloria, this intimacy between majesty and inoperativity, found an exemplary symbol (...) in the image of the empty throne". The emptiness of the

\footnotetext{
${ }^{4}$ According to Agamben (2008, p. 331), Gloria "expresses the uncertain zone in which acclamations, ceremonies, liturgy and insignia move". It thus characterizes the set of symbolic aspects of Christian worship and what articulates the relationship between immanence and transcendence in the complementary duality of the Trinitarian order (PFISTER, 2019).

${ }^{5}$ Divine inoperativity manifests itself in the Judeo-Christian tradition in some ways: on the Jewish Shabbat and the promise of eternal life, for example (PFISTER, 2019).
} 
throne is an integral part of the inoperativity at the heart of Glory, and that Glory must take advantage to operate. In other words, for this power to be maintained in the government of men and for divine inoperativity to be praised, it is necessary to capture in man its inoperativity, transforming it into operativity. According to Pfister (2019, p. 119), "power needs Glory precisely because it watches over and at the same time captures essentially human inoperativity, ceaselessly devoting it to work, the execution of a work, of duty, of a craft". This is how, according to Phelps (2012, p. 1), "that inoperativity is the political substance of the Occident, the glorious nutrient of power".

Agamben (2008, p. 12), in this way, also identifies the "glorious" aspect of Christian theology with the oikonomia organization, which has in its acclamatory form of "consensus" its specific contribution and whose original paradigm is found in medieval treaties and about the divine government of the world. For the author, the government machine's center is empty, which is perhaps, the most significant symbol of power. In this sense, it is argued that, just as the glorious aspect of power remains in the administration of the world even with the finiteness of the divine oikonomia project, so also the aspects of power domination, and control, now gloriously, remain on flexible organizations, insofar as there is no break with bureaucracy, but an adaptation of organizations to a productive restructuring (PAES DE PAULA, 2002; SILVA 2003).

The glorious aspect of power present on flexible organizations is also reflected, among other aspects, in its ceremonial and liturgical majesty. The function of acclamations and Glory, in the form of consensus, is at the center of the political devices of this society, according to Agamben (2008).

If the media are so important in modern democracies, it is not due, in effect, only to the fact that they allow the control and government of public opinion, but also and above all because they administer and grant Glory, that acclaim and doxological aspect of power that in modernity seemed to have disappeared. The society of the spectacle - if we call contemporary democracies by this name - is, from this point of view, a society in which power in its "glorious" aspect becomes indiscernible from oikonomia and government (AGAMBEN, 2008, p. 11).

As a result, flexible organizations emphasize "socialization programs for two individuals via training or learning through the use of symbolic elements" that "reinforce the organizational beliefs and the spirit that 'we are a special time and together we will obtain success" (PRESTES MOTTA, 1993, p. 74). This sense or symbolic manager encourages the rites and celebrations (parties and fraternizations, names of time, names, cores, or images that represent teams, etc.) of a subgroup of the organization, trying to relate it to the same culture, which does not overbid on this process.

In the same way that God gives free-arbitration to his creatures, the company grants its employees freedom of escort to execute their activities. However, we have two cases still resisting the operation's capture in favor of the promise of inoperativity: there is a destination to come (paradise), a work to be carried out, an order to be executed, which is not annulled with a concession of limited freedom. In any case, you seem to leave free or home; when a real operation has a much stronger subjective control, one time in both of them, there is something invisible that observes the operation (PAGÈS, BONETTI, GAULEJAC et al., 1993; PRESTES MOTTA, 2001 ). There is no more formal control figure, to his answer, it also becomes more complicated: how will he get rid of a ghost?

For Agamben (2008, p. 7), the divine paradigm of men's government is not tyrannical but democratic. Starting with Leibniz, the author explains that "God rules everything irresistibly, but sweetly and without violence, so that man believes he follows his will while executing God's". Similarly, a model is established in which the manager "governs" his functionaries through subtle and imperceptible solidarity, as they are governed by themselves. The flexible organizations are evident in the measure that the government over men transcends not through coercion or by the hierarchical authority, but by a series of technologies of power related to the practice of the government of men, among which the legal system, disciplinary mechanisms, and security devices, capable of producing governable subjects by capturing their subjectivity (FONTOURA and BIROCHI, 2015; AGAMBEN, 2008).

According to the genealogical investigation of the theology of the economy and the government of Agamben (2008, p. 195), governmental techniques of men dominance, which are evident in flexible organizations, as we will see below, they have their origins in the Christian pastorate, which develops a "government of souls" and which, "as a 'technique of techniques', defines the activity of the Church until the eighteenth century, when it becomes the 'model' and 'matrix' (... ) of political government". Agamben (2008) affirms that some characteristics are essential for the Christian pastorate. It refers both to individuals and 
totality, taking care of omnes et singulatim (all and each). As a governmental technique, the pastorate is individualizing and totalizing because, by treating members in a fragmented way, it disarticulates them politically.

This political uprooting of members of participatory-oriented organizations, as the flexible ones, is highlighted by Tragtenberg (2005), for whom disciplinary manipulation techniques blame the individual for what is produced on a social level. Tragtenberg cites massive use of gratifications of the symbolic order, the techniques of consultation, and individual consultations that seek to control hostility and measure the individual's level of loyalty to the organization. It can be seen that these techniques bear a close resemblance to those used by the Christian pastorate to control the lives of the faithful: confession, counseling, blame for the idea of sin, symbolic gratification (in this case a posteriori, with the image of paradise), among others, which are used to maintain order. A complete difference here is given by the fact that the flexible organization is "covered by a layer of rationalism and logicity", which contributes to "sacralization of the company as an institution - it begins to have a 'social function', appears as an extended family, guaranteeing its members fulfillment and individual satisfaction," functioning as the Church and giving a meaning to the lives of its employees (TRAGTENBERG, 2005, p. 33-34).

Agamben (2008, p. 195) takes up Foucault to demonstrate that another essential aspect that Christian pastorate and government share is "the idea of an 'economy', that is, an administration of individuals, things, and wealth ordered according to the model of the family". The manipulation, anguish, and blame of the individual operated by this form of management that brings together a family idea promotes political apathy in the members, because according to Tragtenberg (2005, p. 40), "every time in the political area you are called 'my children', the sphere of your political rights disappears". This invasion of individual's subjective and sensitive dimensions signals a new strategy for flexible organizations comparing to bureaucratic ones with regard to the dynamics of ordering between work and pathos.

As indicated, there is a substantial redirection of pathos in this glorious dynamics of capturing inoperativity while managing pleasure and channeling aggressiveness to productive potential. According to Prestes Motta $(1981$, p. 35), in this sense, "it is necessary to channel all the forces that can be productive, and to do so it is not enough to punish or repress, but it is essential to keep a discreet and permanent watch". This permanent vigilance constitutes, in truth, a belief system and an ideal of life embodied in rules that are not formal, but that function as "a commandment, which is based on the omnipotence of each one's unconscious" (PRESTES MOTTA, 1981, p. 35). This surveillance system works similarly to divine surveillance over creatures that occurs through God's omnipresence. Agamben (2008) argues that this shadow imposes itself and is present, as a symbol of Glory, that remains to be desecrated.

\section{SACRALITY AND BUREAUCRATIC AND FLEXIBLE ORGANIZATIONS: FINAL REFLECTIONS}

This theoretical essay sought to bring together Christian theology and administration, seeking to establish relations between aspects related to Christian theology and its Trinitarian order and the characteristics of bureaucratic and flexible organizations by problematizing the idea of secularization and rationality that goes through them. However, the proposal did not aim to end a reference of these organizations to their divine originality, excluding all other relationships that, over time, shaped their ways of organizing and the relationships of power and domination that permeate them. The objective was to shed light on the possible relations and references between the divine oikonomia organization and the bureaucratic and flexible organizations.

Based on these relationships and the observation of a new type of sacralization in these organizations that, without breaking with the divine ideal, make economic power, money, technique, and formal logic sacred over everything else, advocates for the desecration of sacred by restoring to the human community what has historically been removed from everyday use through sacralization. It is understood that this exit can occur through reflections about inoperativity and its relationship with politics and aesthetics, which refer to a new possibility of using pleasure, desire, and the body. In this space, we try to make some notes on this topic, without, however, exhausting the discussion, as the concept of inoperativity and its articulations remain open in Agamben's work, as an invitation and political task for the next generation.

The concept of inoperativity is particularly essential because it is part of how glorious power, through its devices, continually launches men to work, transforming their inoperativity into operativity (AGAMBEN, 2008). As discussed, these devices are 
widespread in organizations and society, inculcating a process of training the soul of individuals (PRESTES MOTTA, 1981, 2001). If this is true and we are always moving between different power devices, one can ask: if it is not possible to delete them, how to disable them? How to use them in another way? (ROSA, 2015).

For Agamben, it is not a question of eliminating but deactivating or rendering inoperative a human power, function, or human operation. This is the political task of desecration, according to the author, who works with the concept of inoperativity in the sense of liberating potentialities, of the possibility of restoring use and not necessarily of disappearances in a record in the file and the memory (PHELPS, 2012; ROSA, 2015). It is important to emphasize that inoperability here as opposed to an operative and productive model. It does not mean merely the opposite of operativity or inertia, but a possibility to contemplate our power, what we can or cannot do, our "power of not".

Inoperativity leads us to abstain from the productive purpose, to a liberation of the economy, and, therefore, to a political movement captured by the first to order bodies effectively and impose a way of being in the world (AGAMBEN, 2008; BÖHM, 2005). Therefore, inoperativity enhances the subversion of ordinary body movements or gestures that qualify the being professionally and "tend to identify human nature with the simple workforce" (TRAGTENBERG, 1974, p. 194).

According to Agamben (2007), what can be done, therefore, is a new use. In the case of capitalism and its form (s) of economic organization constituted as a religion, Agamben (2007) defends a desecration of what cannot be desecrated as the next generation's political task. For the Italian philosopher, even if capitalism is that religion that invades everything in an unceasing cult, it is about seeking liberation "from the consumerist asphyxiation in which we are involved", and also, at the same time, moving away from sacralization "of reason above all", calling attention "to the impersonal, the obscure, the pre-individual of each of our lives" (AGAMBEN, 2007, p. 9).

For Agamben (2005), through politics, one could think of such a perspective of free use of the world, a dimension that has always been concealed, whether in the Christian pastorate or the forms of government employed in the scope of capitalism. Böhm (2005) corroborates this understanding by stating that the repositioning of the idea of organization requires political intervention, which does not shy away from considering the political, economic, and historical aspects. In the sense of polemicizing the dominant order, Agamben (2008, p. 371) argues that aesthetics, which inevitably refers to the profane sphere of pleasure, desire, and jouissance, is precisely the "price to be paid if one is to detach the theory of glory from the sphere of Gewalt [violence], of power". Also for Rancière (2009, p. 11-12), "today, it is in the aesthetic field that a battle continues yesterday centered on the promises of emancipation and the illusions and delusions of history", because aesthetic acts, as configurations of experience, "give rise to new ways of feeling and induce new forms of political subjectivity".

It is important to note that Agamben and Rancière do not refer here to a modern idea of aesthetics, inasmuch as they refuse objectivity, rigidity, and the authorized and closed representation of art that is made in this sense. Although starting from different matrices, the two philosophers touch on the political issue "as a power capable of deactivating desubjectivation devices" (MOURA and ALMEIDA, 2014, p. 120). Both converge to the idea that this process of questioning pre-distributed places and identities, insofar as it operates deconstructions and interventions in the visible and the sayable and is not related to a specific purpose, but it is an endless means, or a means itself, is entangled in the aesthetic issue (AGAMBEN, 2008; RANCIÈRE, 2009). Thus, in contemporary times, "art is the inoperative activity par excellence, because, from the moment it is not restricted to oeuvrer, that is, to produce works, it allows to escape any productive end imposed by capitalism" (MORAES, 2019, p. 1).

According to Rancière (2009, p. 64-65), "the distribution of the sensitive ${ }^{6}$ makes the worker a double being (...) when the principle of a well-organized society is that each one does only one thing, the one to which its "nature' destines it". In this sense, according to the author, the democratic distribution of the sensitive experience removes the worker from "his" place, the domestic space of work, and allows him "to be in the space of public discussions and the identity of the deliberating citizen". Returning to the idea of the "aesthetic" state described by Schiller in Letters for the aesthetic education of man, Rancière $(2009$, p. 66) warns that there is a theoretical and political operation that consists in wanting to "ruin, with an idea of art, an idea of a society founded on the opposition between those who think and decide and those who are destined for material work".

\footnotetext{
${ }^{6}$ Rancière (2009) considers a specific notion of aesthetics as the distribution of the sensible in which specific modes of articulation between perceiving, thinking, producing, and acting are determined. This distribution regime is related to a political perspective of aesthetics, which is opposed to police distribution.
} 
In this sense, contemporary artistic practices and their related forms of organization can be an important field of investigation of what is pointed out by Agamben (2007) and Rancière (2009). According to Benhamou (2007), Durand (2007) and Bendassolli, Wood Junior, Kirschbaum et al. (2009), the cultural sector has a series of peculiar characteristics concerning the way individuals and groups organize themselves, as the choices of cultural organizations go through aesthetic and artistic conceptions, unlike traditional industries, where rationality, functionality and the search for effectiveness and efficiency direct the use of resources.

Finally, this theoretical essay understands that it is necessary to bring organizational thinking to the sphere of the human, which admits contradiction, which is mutable, which is dual and not one, and which expresses sensitivity insofar as it is not, and could not be, just spirituality or reason. From this, it is necessary to carry out the political task of thinking about organizations from other categories that also comprehend the sphere of the sensitive, aesthetics, and pleasure, profaning the split that has been undertaken for a long time between logos and pathos. 


\section{REFERENCES}

ADORNO, T.; HORKHEIMER, M. Dialética do esclarecimento. Rio de Janeiro: Zahar Editores, 1985.

AGAMBEN, G. El Reino y La Gloria: una genealogía de la economía y del gobierno. Homo Sacer II, 2. Buenos Aires: Adriana Hidalgo, 2008.

AGAMBEN, G. Profanações. São Paulo: Boitempo, 2007.

ALBAUM, G.; PETERSON, R. A. Ethical attitudes of future business leaders: Do they

vary by gender and religiosity? Business and Society, v. 45, n. 3 , p. 300-321, 2006.

ASHFORTH, B.E.; VAIDYANATH, D. Work organizations as secular religions. Journal of Management Inquiry, v. 22, p. 359-370, 2002.

ASHMOS, D.P.; DUCHON, D. Spirituality at work: A conceptualization and measure. Journal of Management Inquiry, v. 9, n. 2, p. 134-145, 2000.

BAZANINI, R.; GIGLIO, E. M. The role of stakeholders in Solomon's Temple: an exploratory study. O\&S - Salvador, v. 24, n. 83 , p. 674 690, 2017.

BÉDARD, R. Los fundamentos del pensamiento y la prácticas administrativas. AD-MINISTER, Medellín, n. 4, p. 80-108, ene-jun, 2004.

BENDASSOLLI, F. et al. Indústrias criativas: definição, limites e possibilidades. RAE - Revista de Administração de Empresas, São Paulo, v. 49, p. 10-18, jan./mar. 2009.

BENHAMOU, F. A economia da cultura. Cotia: Ateliê Editorial, 2007.

BERGER, P. L. Os múltiplos altares da modernidade: rumo a um paradigma da religião numa época pluralista. Petrópolis: Vozes, 2017.

BERNARDELLI, L. V.; MICHELLON, E. O Impacto da Religião no Crescimento Econômico: Uma Análise Empírica para o Brasil em 1991, 2000 e 2010. Estudos Econômicos (São Paulo), v. 48, n. 3, p. 489-523, 2018.

BÖHM, S. Repositioning Organization Theory: Impossibilities and Strategies. Basingstoke: Palgrave, 2005.

CLEGG, S. As Organizações Modernas. Oeiras (PT): Celta Editora, 1998.

COSGEL, M.; MINKLER, L. Religious Identity and Consumption. Review of Social Economy, v. 62, p. 339-350, 2004.

CORRÊA, V. S.; VALE, G. M. V.; CRUZ, M. A. Entrepreneurial Orientation and Religion: The Pastor as an Entrepreneur. Revista de Administração, v. 52, n. 3, p. 330-340, 2017.

CUNHA, J. A. et al. Innovation in a religious environment: establishing an inter-organizational network oriented to the Islamic market. Revista de Administração Mackenzie, v. 17, p. 122-155, 2016.

DUCHON, D.; PLOWMAN, D. A. Nurturing the spirit at work: Impact on work unit performance. Leadership Quarterly, v. 16, p. 807-833, 2005.

DURAND, J. C. Prefácio. In: BENHAMOU, F. A economia da cultura. Cotia: Ateliê Editorial, 2007. p. 11-14.

ENOQUE, A. G.; BORGES, A. F.; BORGES, J. F. Religião e consumo: aspectos conceituais, limites e possibilidades. Farol - Revista de Estudos Organizacionais e Sociedade, Belo Horizonte, v. 2, n. 4, p. 488-532, 2015.
FARIA, J. H.; MENEGHETTI, F. Burocracia como organização, poder e controle. RAE-Revista de Administração de Empresas, São Paulo, v. 51, p. $424-439,2011$.

FINCH-LEES, T.; MABEY, C.; LIEFOOGHE, A. 'In the name of capability': a critical discursive evaluation of competency-based management development. Human Relations, v. 58, p. 1185-1222, 2005.

FOUCAULT, M. A Ordem do Discurso. São Paulo: Loyola, 1996.

FONTOURA, D.; BIROCHI, R. Organizações Flexíveis como Prática de Governamentalidade. In: V COLÓQUIO LATINO-AMERICANO DE BIOPOLÍTICA; III COLÓQUIO INTERNACIONAL DE BIOPOLÍTICA E EDUCAÇÃO; XVII SIMPÓSIO INTERNACIONAL IHU, 2015, São Leopoldo. Anais... São Leopoldo: Unisinos, 2015.

GREY, C.; GARSTEN, C. Trust, control and post-bureaucracy. Organization Studies, v. 22, n. 2, p. 229-249, 2001.

HARRISON, S. H.; ASHFORTH, B. E.; CORLEY, K. G. Organizational sacralization and sacrilege. Research in Organizational Behavior, v. 29, p. 225-254, 2009.

HUBER, G.; GLICK, W. (Ed.). Organizational change and redesign. New York: Oxford, 1995

IBARRA-COLADO, E. Organization Studies and Epistemic Coloniality in Latin America: Thinking Otherness from the Margins. Organization, v. 13, p. 463-488, 2006.

KELLER, A. C.; SMITH, K. T.; SMITH, L. M. Do gender, educational level, religiosity, and work experience affect the ethical decision-making of U. S. accountants? Critical Perspectives on Accounting, v. 18, n. 3, p. 299-314, 2007.

LUDUEÑA ROMANDINI, F. Capitalismo y secularización. Filosofia Unisinos, v. 12, p. 98-113, maio/ago. 2011.

MARTES, A. C.; RODRIGUEZ, C. Afiliação religiosa e empreendedorismo étnico: o caso dos brasileiros nos Estados Unidos. Revista de Administração Contemporânea, v. 8, n. 3, p. 117-140, 2004.

MARTINEZ, A. L.; COELHO, M. L. B. Tax morals and the Brazilian citizen: an empirical study. Cadernos EBAPE.BR, Rio de Janeiro, v. 17, n. 3, p. 607-622, jul./set. 2019.

MILBANK, J. Teologia e teoria social. São Paulo: Loyola, 1995.

MOLTMANN, J. Trindade e o Reino de Deus: uma contribuição para a teologia. Petrópolis: Vozes, 2000.

MORAES, J. I would prefer not to: sobre o conceito de inoperosidade em Giorgio Agamben e a arte contemporânea. Viso: Cadernos de estética aplicada, v. 13, n. 24, p. 168-192, 2019.

MOURA, A. C.; ALMEIDA, H. T. N. Perspectiva do conceito de político à luz da filosofia de Jacques Rancière e Giorgio Agamben. Cadernos de Ética e Filosofia Política, n. 25, p. 108-123, 2014.

NASCIMENTO, C. G. Ética e cristianismo: a busca de um consenso para o século XXI na concepção de Leonardo Boff. Pensamento \& Realidade, v. 17, p. 113-144, 2005.

NELSON, R. E. Authority, organization, and societal context in multinational churches. Administrative Science Quarterly, v. 38, p. $653-682,1993$. 
NIETZSCHE, F. W. A Gaia Ciência. São Paulo: Companhia das Letras, 2001.

OLIVEIRA, L. L. S.; CORTES, R. X.; BALBINOTTO, G. A economia da religião e seus fundamentos: teste de um modelo de escolha religiosa. Estudos Econômicos, v. 41, n. 4, p. 811-840, 2011.

PAES DE PAULA, A. P. Tragtenberg revisitado: as inexoráveis harmonias administrativas e a burocracia flexível. Revista de Administração Pública, Rio de Janeiro, v. 36, p. 127-144, jan./fev. 2002.

PAGÈS, M. et al. O poder das organizações. São Paulo: Atlas, 1993.

PAIVA, L. E. B. et al. Planned behavior and religious beliefs as antecedents to entrepreneurial intention: $A$ study with university students. Revista de Administração Mackenzie, São Paulo, v. 21, n. 2, eRAMG200022, 2020.

PALMER, I.; BENVENISTE, J.; DUNFORD, R. New Organizational Firms: Toward a Generative Dialogue. Oganization Studies, v. 28, n. 12 p. 1829-1847, 2007.

PARKER, M. Against Management: Organization in the Age of Managerialism. Cambridge: Polity Press, 2002.

PARKER, J. Z.; BAKER, J. What would Jesus buy: American consumption of religious and spiritual material goods. Journal for the Scientific Study of Religion, Malden, v. 46, n. 4, p. 501-517, 2007.

PFISTER, M. Oikonomia trinitária na obra de Giorgio Agamben: entre o reino e a glória, Opus Dei e altíssima pobreza. Campinas: PUC-Campinas, 2019.

PHELPS, H. Performing Profanation: Giorgio Agamben's Non-NonChristianity. Political Theology Network, 27 nov. 2012.

PRESTES MOTTA, F. A propósito da "sociedade organizacional". RAE-Revista de Administração de Empresas, São Paulo, v. 18, p. 71-75, 1978.

PRESTES MOTTA, F. O poder disciplinar nas Organizações Formais RAE-Revista de Administração de Empresas, São Paulo, v, 21, p. 33-41, out./dez. 1981.

PRESTES MOTTA, F. O que é burocracia? São Paulo: Editora Brasiliense, 1991.

PRESTES MOTTA, F. Controle Social nas Organizações. Revisitado por Isabella F. F. Gouveia de Vasconcellos e Thomaz Wood Junior. RAE-Revista de Administração de Empresas, São Paulo, v. 33 p. 68-87, set./out. 1993.

PRESTES MOTTA, F. A organização como religião laica. O\&S - Salvador v. 8, n. 22, p. 1-23, 2001.

RANCIÈRE, J. A partilha do sensível: estética e política. São Paulo: EXO experimental org.; Ed. 34, 2009.
RAMOS, A. G. A Sociologia de Max Weber (sua importância para a teoria e prática da administração). Revista do Serviço Público - textos históricos, Brasília v. 57, p. 267-282, abr./jun. 2006.

ROSA, A. Do conceito de inoperosidade para a potência de agir em Agamben. Seara Filosófica, n. 11, p. 21-34, 2015.

SERAFIM. M. C.; ANDION, C. Capital espiritual e as relações econômicas: empreendedorismo em organizações religiosas. Cadernos EBAPE.BR, Rio de Janeiro, v. 8, n. 3, p. 564-579, 2010.

SERAFIM, M. C.; MARTES, A. C.; RODRIGUEZ, C. "Segurando na mão de Deus": organizações religiosas e apoio ao empreendedorismo. RAE-Revista de Administração de Empresas, São Paulo, v. 52, n. 2, p. 217-231, 2012.

SERAFIM, M.; FEUERSCHÜTTE, S. G. Movido pelo transcendente: a religiosidade como estímulo ao "espírito empreendedor". Cadernos EBAPE.BR, Rio de Janeiro, v. 13, n. 1, p. 165-182, 2015.

SILVA, R. C. Controle organizacioanal, cultura e liderança: evolução, transformações, e perspectivas. Revista de Administração Pública, v. 37, n. 4, p. 797-816, 2003.

SOUSA, E. S. et al. The influence of religious beliefs on entrepreneurial intention: an analysis from the perspective of the Theory of Planned Behavior. Cadernos EBAPE.BR, Rio de Janeiro, v. 18, n. 1, jan./mar. 2020.

SOUTO, C. A. T. Nietzsche e Foucault: da morte de Deus à morte do homem. SABERES, Natal, v. 1, n. 6, p. 129-141, fev. 2011

SPICER, A.; ALVESSON, M.; KARREMAN, D. Critical Performativity: The Unfinished Business of Critical Management Studies. Human Relations, v. 62, n. 4, p. 537-560, 2009

SPICER, A.; ALVESSON, M.; KARREMAN, D. Extending critical performativity. Human Relations, v. 69, n. 2, p. 225-249, 2016.

STEINGARD, D. S. Spiritually-informed management theory - Toward profound possibilities for inquiry and transformation. Journal of Management Inquiry, v. 14, n. 3, p. 227-241, 2005

TRACEY, P. Religion and Organization: A Critical Review of Current Trends and Future Directions. The Academy of Management Annals, v. 6 , n. 1, p. 87-134, 2012

TRAGTENBERG, M. Burocracia e ideologia. São Paulo: Ática, 1974.

TRAGTENBERG, M. Administração, Poder e Ideologia. 3. ed. rev. São Paulo: Editora UNESP, 2005

VASCONCELOS, A. F. The Spiritually-Based Organization: A Theoretical Review and its Potential Role in the Third Millennium. Cadernos EBAPE.BR, Rio de Janeiro, v. 13, n. 1, p. 183-183, 2015.

WALKER, A. G.; SMITHER, J. W.; DEBODE, J. The Effects of Religiosity on Ethical Judgments. Journal of Business Ethics, v. 106, n. 4, p. 437-452, 2012. 
MMaster in Business Administration from the Federal University of Santa Catarina (UFSC); Researcher associated with the Observatory of Organizational Reality (UFSC), Florianópolis - SC, Brazil. E-mail: aline.neutgem@gmail.com

Eloise Helena Livramento Dellagnelo

ORCID: https://orcid.org/0000-0001-7586-0302

Ph.D. in Production Engineering from the Federal University of Santa Catarina (UFSC); Professor in the Postgraduate Program in Administration at the Federal University of Santa Catarina (UFSC), Florianópolis - SC, Brazil. E-mail: eloiselivramento@gmail.com 